Narrative Strategies in Culture, Translation and Media: Stories of Beslan as a Test Case

\author{
Ludmila KOMUTSTSI \\ Dr. Sc. in Philology \\ Professor \\ Department of Translation and Translation Studies \\ Sevastopol State University \\ 33, Universitetskaya str., Sevastopol, 299053, the Russian Federation \\ $+79873084271$ \\ $\underline{\text { ltataru@yanedx.ru }}$
}

\title{
Saule ALTYBAYEVA
}

Dr. Sc. in Philology

Head Researcher

Associate Professor

Kazakh Ablai khan University of International Relations and World Languages 200, Mukhanov str., Almaty, The Republic of Kazakhstan

$+77024999438$

altybayevasaule@gmail.com

\begin{abstract}
One of the key guidelines humanities can safely use today, as they are negotiating the cultural turn both on the methodological and on the daily bases, is set by the narrative theory. Diversity of research paradigms is hindering the search for efficient tools that can be applied to settling up intercultural and international conflicts. However, among the multitude of turns there is one that appears to stand out against the cultural-theoretical landscape, namely, the social theory of translation which draws on the methodology of the narrative theory and, accordingly, applies narrative strategies to analysing translations in the context of social and political crises. This article discusses some narrative strategies adopted by the social theory of translation and by the media studies. By analysing such strategies in Yuri Dude's documentary "Beslan. Remember" and comparing it to the American documentaries "Citizenfour: The Truth of Snowden", "The Jinx" and
\end{abstract}


to the art-documentary essay "The School" about Beslan, the authors suggest that the use of narrative techniques, irrespective of their artistic mastery, has a power strong enough to transform reality and that further research into narrative strategies has serious perspectives for the social translation theory, journalism and other humanist disciplines.

Keywords: the cultural turn; narrative; social theory of translation; media; documentary film; Beslan.

\section{Introduction}

Since the 1990s humanist sciences have been living in the state of a revolution known as "the cultural turn". One of its consequences of this process may be seen in the growing importance of translation for settling up political, economic and intercultural conflicts, for overcoming the antagonism between dominant cultures like those of the United States and the United Kingdom and the post-colonial minority cultures and for the ongoing struggle against the discrimination of the minority languages and cultures within multicultural societies. In Russia, due to its specific political and economic relationships with the Western world, scholars tend to take a contemplative theoretical stance towards the diversification of the cultural turns (Bezuglova, 2010; Moshonkina, 2016), while the global turn towards translation in its proper sense tells on nothing more than individual attempts to analyse the translation strategies used for texts written in English (Kornaukhova, 2011; Shelestyuk, Gritsenko, 2016). This implies that the applied aspects of translation as a category of intercultural communication have not yet been transferred to the context of the Russian intra-national relations, which have to establish themselves in a rather unfavourable context of reinforcing the official status of Russian as the language of power.

Both the Westerrn and the post-colonial turns themselves, however, seem to stay rather far away from any articulate theoretisation. On the contrary, the multiplicity of research paradigms and points of view is hindering the search for operative tools that may be used to overcome the intercultural and international conflicts. The conception that appears to stand out against the conflicting theoretical landscape is the social theory of translation. This conception draws on the methodology of the narrative theory and, accordingly, applies narrative strategies to analysing translations in the context of social and political crises. The same strategies have been massively involved in transforming the media, which tend to bring storytelling into play along with the conventional formats of informing and instructing the audience. This article will therefore present a narrative approach to some critical problems of translation with the purpose of highlighting the 
social and intercultural significance of the narrative strategies and their importance for the Russian media studies and translation studies.

\section{Methods}

The principal material taken for the analysis in this article is the documentary film "Beslan. Remember" by Yuri Dude. It premiered on You-tube in September 2019, on the $15^{\text {th }}$ anniversary of the terrorist act in Beslan, to gather a multimillion audience immediately (Dude, 2019). This media product is examined using the methods of comparative, structural and social narrative analysis. The analysis of the film is preceded by a theoretical consideration of the concept of narrative used by the social translation theory and by media studies.

Literature review. One representative illustration of the diversity of points of view existing currently in the science of translation can be found in Mary Snell-Hornby's book "The Turns of Translation Studies" (2006). The cultural twists and turns include multimedia translation, postcolonial and gender theories of translation, the effects of new technologies and globalization (including the leading role of the English language in it and the imperial thinking), etc. The book ends with the reflections on the dubious achievements of the new "methodological paradigms". In particular, the Austrian scholar expresses her disagreement with the concept of equivalence and insists on cleansing the metalanguage of translation studies from the heavy terminology to bring it closer to real-life communicative situations. Another conceptualisation of the cultural turns and an attempt to transfer them from the idea to practical analysis are suggested in the book written by the German cultural scholar Doris Bachmann-Medick (2017). The author explains the ability of the applied aspects of the cultural turns "to sustain the tendency to metaphorise their own categories" and to transform translation as a linguistic concept into the metaphor of "the translation of cultures". In the introduction, Bachmann-Medick (2017) emphasizes, that the impulses of various "turns", the linguistic one including, are forming a global "metanarrative of the Cultural Turn" thus forcing the researchers move "from the dominance of representation ... towards corporeality and action, towards the politics of social and intercultural differences along with the practice of translating and overcoming them". The metaphor "Metanarrative of the Cultural Turn" is quite indicative of the diversification within translation studies and other humanist disciplines, and yet it cannot be claimed that they have lost a strategic and methodological reference point altogether. Such a point rests on the narrative - a concept originally confined to literary theory but having transcended its borders to gain an interdisciplinary status and to drift from theory to the mass public discourse. 
What helped narrative become a widely recognized tool of cognition does not lie so much in its aesthetic (structural) features, but rather in its deep, prototypical characteristics common to its different types. David Herman defines them as: 1) situatedness - placing a representation into a specific discourse context or occasion for telling; 2) event sequencing - the inferences interpreters draw about a structured time-course of particularized events; 3) worldmaking / world disruption - a disruption these events introduce into a storyworld involving human or human-like agents, whether that world is presented as actual or fictional; 4) "what's it like?" - the experience of living through this storyworld-in-flux the representation conveys, highlighting the pressure of events on real or imagined consciousnesses. David Herman (2009) argues "that narrative is centrally concerned with qualia, a term used by philosophers of mind to refer to the sense of 'what it is like' for someone or something to have a particular experience". Recent research on narrative bearing on the nature of consciousness itself has been done in numerous studies on not only literary, but also "living", nonfictional stories (Georgakopoulou, 2017).

Sociologists define narrative as an active tool for constructing reality, a way of cognizing and ordering it, of forming a person's identity and actions (Bruner, 1991). Our cognition occurs through the imposition of a narrative form on real events in order to make sense of the world around us, as narratives are versions of reality with their plots, heroes and events. The degree of the impact a narrative may have on reality is determined by its type - personal, public, conceptual or a metanarrative one (Somers, Gibson, 1994). Mona Baker's monograph "Translation and Conflict" (2006) has played a decisive role in the recognition of the social-constructivist theory of narrative for translations and translators. She gave impetus to a research on modifications of the narratives of Beslan hostages in the English translations (Harding, 2012), on translation analysis of migrant narratives (Baynham, De Fina, 2016), the narratives of translators-activists and volunteers (Cabezas Bravo, 2018), the formation of associations and symposia on the narrative theory of translation (Kim, Harding, 2015).

Another impact of narrative as a tool of knowledge and experience may be observed in the emergence of narrative journalism in the 1990s with its focus on the creation of media and transmedia stories. This sub-discipline of the narrative theory is enjoying a sweeping popularity in the West to echo the growing demand on non-fiction literature and cinema: the best documentaries are created drawing on the laws of the artistic genres, while the new literature and cinema are generously adopting blogs and other documentary genres of social networks, in conformity with the principles of activism and narrativization with an ideological accent (Harshini, Jayaneela Sneha, 
2019). Some qualitative research in this area, on television documentary in particular, is being done in Russia, too (Pronin, 2016).

\section{Results}

Dude's documentary about Beslan is not a very typical piece of media storytelling in Russian journalism. The author appeals to one of the mainstream narratives of the early 21 st century, which, along with the 9/11/2001 terrorist attack in New York, opened the epic drama of the era called now "Terrorism" or "The Hybrid Wars". During the fifteen years that have passed since Beslan tragedy, Russian newspapers and TV channels were used to issue but scanty notices on the days of the anniversaries, which gave Sue-Ann Harding the reason to call them "The narratives of silence" (Harding, 2020). The first poignant publicist narrative about Beslan, "The School", was written in 2006 by the American war reporter, long-form writer and multiple Pulitzer Prize winner Christopher John Chivers (2007). He traveled to Beslan several times to immerse himself into the world of its tragedy (immersion being one of the conditions for creating a narrative), talked with the surviving hostages and wrote a documentary story that showed the collective experience of horror and the manifestation of such superior human qualities as courage, self-sacrifice and kindness right in the midst of it. That was a story written at the crossroads of a journalistic investigation, a chronicle and a psychological thriller.

A story of the collective memory of Beslan, equal in human power and depth to "The School", has not appeared in the Russian media yet. Chivers' story (2019) was published in the Russian version of Esquire no earlier than by the fifteenth anniversary of the tragedy and, for some reason, the translator left it without the original title. Generally speaking, a noticeable shortage of translations of documentary narratives or sociological studies of crisis processes from Russian to foreign languages and vice versa and, likewise, a lack of stories written in the national languages of Russia and the former CIS countries, may be seen as a distinct technique of "defamiliarization" from the traumatic experience of the people who have lived through or are going through a crisis today.

The fifteenth anniversary of the Beslan tragedy, all of a sudden, witnessed a real "Beslan breakthrough". Three documentaries were released on the You-Tube platform at once: "School Number One” by “The Novaya Gazeta", Yuri Dude's "Beslan. Remember” and a bit less successful project by Ksenia Sobchak. At the same time, the story of Beslan was given much lower profile on the federal TV channels while the viral effect of Dude's project triggered quite an aggressive reaction on the part of federal journalists who issued numerous publications packed with phrases like "cheesy pop about the tragedy", "filth and rot" and other expressions of that nature (Apuleev, 
2019). One common argument most critics based their denouncement on said that it was the state, not the terrorists that Dude had profiled as "the evil". An understanding of the key to the success of the film was found in just one paragraph: "It is suppression of evidence and non-availability of any explanation of the logic behind the security forces' actions that gives undereducated young men like 'dude' the opportunity to interpret their actions as the "cannibalism" of the state and of the security officials" (Barshevsky, 2019).

Yuri Dude, unlike the American investigator Chivers, declared his ideological position in the very beginning of the film: "At some point the state made the mistakes that led to trouble, and now the state must encompass all those who had suffered with care and attention." The legitimacy of this position is not the concern of our analysis. The more so because the prosecutors' investigation of the terrorist attack has not been completed yet and the official truth about Beslan still does not cover many questions. We claim that it is not so much the counter-official ideological setting the film owes its massive success to, but its structure, which actively uses the storytelling techniques.

"Beslan. Remember" is a journalistic investigation combining two types of interviews, namely, those revealing the survivors' stories and those of the journalists and other observers who reveal numerous facts about that terrorist attack. Although Dude, unlike the author of "The School", reports the Beslan victims' personal stories just by direct interviews, without resorting to internal monologues or other artistic methods, the very choice of the "ordinary people's" perspective, unusual for the Russian documentaries, impressed the audience. This perspective, too, gave the critics the reason to accuse the director of a biased selectivity in the presentation of facts so "harmful" for the state.

Its publicistic analyticity and the system of arguments the documentary owes to the stories of "The Kommersant" correspondent Olga Allenova, "The Novaya Gazeta" journalist Elena Milashina, both of whom are leading their own investigations of the Beslan events, the interviews with Ingushetia's ex-President Ruslan Aushev and other officials. It is not so much their evidence, however, but the collage of the stories told by the then-schoolgirls and schoolboys that make the film into "true documentary filmmaking" (Barshevsky, 2019). The expressions of their faces as they tell their stories give an intense emotional momentum and an immersive effect to the film. It is this essential quality of the film intrinsic to a narrative that, in D. Herman's terms, is known as qualia (What's it like?) that helps the narrative appeal not to the logic but to the emotions of the viewer who is internalizing the characters' terrific experience. 
The storytelling approach also elicited the viewers' active response, showing the positive effect of the moral lesson of the film. The very next day after the premiere, Marina Duchko, a wheelchair user who makes odd income on selling her violets in Instagram, found that the number of her followers had increased several folds. Her income had grown thanks to her new Instagram followers. The viewers also raised funds for the rehabilitation of two other heroines, Diana Murtazova who is also moving around on a wheelchair, and Fatima Dzagoeva, a victim to cerebral injury.

Having shown the overall effect of its narrative strategy, Dude's documentary, however, can hardly be measured up to the best American documentaries both in the directing art level and in the levels of its impact. To compare, "Citizenfour. The Truth of Snowden", recipient of the 2015 Emmy Award for "Exceptional Merit in Documentary Filmmaking", was made as a spy thriller in the cinema-verite technique. The director Laura Poitras was the narrator and the character whose connection to the material could hardly be more direct: she had received encrypted messages from Snowden himself to become a participant of an eight-day covert hotel-room interview with him. Poitras, however, had made a choice not to be seen on the camera and to be only a "voice-over" speaking in a conspiratorial jargon. The revelations that emerged from "Citizenfour" appear to have resulted in important changes relative to perceptions of Edward Snowden and public sentiment about NSA surveillance for the American, British and German publics in a way that made counternarratives about security by their states impossible (Winner: Citizenfour. The Doc Impact Award, 2016).

Another example, Andrew Jarecki's "The Jinx", is a film that won an Emmy award in the nomination "The Best Documentary TV Series". It is a biopic of the real estate millionaire Robert Durst, an investigation of a whole series of his unproven murders and a film-psychoanalysis. Throughout all the six docu-series "His twitches took center stage as viewers tried to link Durst's unusual eye movements to his numerous lies and omissions", until an accidental moment of truth did not prove their guesswork: he spilled out that he "had killed them all, of course" to be arrested before the final episode (Gorbachov, Drell, Kutner et al., 2015).

\section{Discussion}

Yuri Dude's documentary "Beslan. Remember" has trigged controversial reactions and a certain activism among the multimillion Russian audience thanks to the use of two methods: an ideological perspective that goes contrary to the official one (the responsibility for the terrorist attack lies with the state) and, most importantly, thanks to the storytelling technique that helped the director 
construct a composition of the eyewitnesses and victims' personal stories. However, this project of Dude's, along with his other successful documentaries, have not yet reached the level of innovation and creativity to claim awards at international festivals.

The project under consideration is accompanied by English and Spanish subtitles, which should sooner or later attract the attention of foreign critics and researchers, especially those engaged in investigating the Beslan metanarrative and its coverage in the Russian media (like Sue Ann Harding). We have not seen their reaction yet, neither have we traced any voices from Russian theorists of journalism and translation so far, though there is a high probability to expect them in the near future.

\section{Conclusion}

The analysis shows that narratives, particularly those made by the media, have the power to impact and to resist the conflicting cultural and political scenarios. They can activate those dialogue techniques that are geared to transform the ideological and linguistic differences into the subject of reflection. Philologists, including translators and authors of media studies, should engage themselves more actively with the cultural turn and the social-constructivist functions of the narratives, since: 1) narratives mediate and construct reality; 2) narrative analysis of the text (translated text, too) provides information on how the narratives behind it construct reality; 3 ) stories, whether personal or media ones, are not just versions of the same story - conflict is embedded in the very process of telling them. Accordingly, the importance of social translation practices that sustain narratives of cultural contact is growing and such narratives need to be created, studied and translated.

\section{Funding}

The article is written as part of the grant project AP05133019 "The Cultural Codes of Contemporary Kazakhstan (Literary and Media Types of Discourse)" funded by The Science Committee of the Ministry of Education and Science of the Republic of Kazakhstan .

\section{References}

Apuleev, I. (2019). Lousy Creep: why Solovjov attacked Dude. Gazeta.Ru. Retrieved from: https://www.gazeta.ru/culture/2019/09/06/a_12630433.shtml (Accessed on January 26, 2020). (in Russian) 
Bachmann-Medick, D. (2017). Cultural Turns: New Orientations in the Study of Culture. Moscow: New Literary Think Piece. (in Russian)

Baker, M. (2006). Translation and Conflict: A Narrative Account. Routledge.

Barshevsky, M. (2019). Hype on the Bones or a Quality Documentary?: social networks on Dude's Film about Beslan. Online media outlet "Topical Comments". Retrieved from: http://actualcomment.ru/khayp-na-kostyakh-ili-kachestvennyy-dokumentalnyy-film-sotssetio-filme-dudya-pro-beslan-1909021837.html (Accessed on January 26, 2020). (in Russian)

Baynham, M., De Fina, A. (2016). Narrative analysis in migrant and transnational contexts. Researching Multilingualism. Critical and ethnographic perspectives. Routledge, 31-45. Retrieved from: https://www.researchgate.net/publication/311328026_Narrative_analysis_in_migrant_and_tr ansnational_contexts (Accessed on January 20, 2020)

Bezuglova, N.P. (2010). Cultural Turn in Western Cultural Studies. Bulletin of the Moscow State University of Culture and Art. 6(38), 21-27. (in Russian)

Bruner, J. (1991). The Narrative Construction of Reality. Critical Inquiry, 18, 1-21.

Cabezas Bravo, V.V. (2018). Weaving a Narrative of Translation, Activism, and Knowledge. Ph.D. dissertation. Erasmus Mundus Masters: Crossways in Cultural Narratives.

Chivers, C.J. (2007). The School. Esquire. Retrieved from: https://www.esquire.com/newspolitics/a1173/esq0606beslan-140/ (Accessed on January 26, 2020).

Chivers, K. (2019). 15 Years Since the Tragedy in Beslan. Hour-by-Hour Chronology of Events in "The New York Times" report. Esquire. Retrieved from: https://esquire.ru/archive/2143beslan/\#part0 (Accessed on January 26, 2020). (in Russian)

Dude, Yu. (2019). Beslan. Remember. Retrieved from: https://www.youtube.com/watch?v=vF1UGmi5m8s\&t=5633s (Accessed on January 26, 2020).

Georgakopoulou, A. (2017). Narrative/Life of the Moment: From Telling a Story to Taking a Narrative Stance. Life and Narrative: The Risks and Responsibilities of Storying Experience. Oxford: Oxford University Press, 29-54. 
Gorbachov, A., Drell, C., Kutner, M. et al. (2015). The Best Documentaries of 2015 (So Far). Newsweek. Retrieved from: https://www.newsweek.com/best-documentaries-2015-so-far337993 (Accessed on September 14, 2020).

Harding, S.-A. (2012). Beslan: Six Stories of the Siege. Manchester and New York: Manchester University Press.

Harding, S.-A. (2020). Translating collective memory of Beslan: Russian state television news coverage of annual commemorations and narratives of silence, othering, separation and abstraction. The Routledge Handbook of Translation and Memory. Retrieved from: https://pure.qub.ac.uk/en/publications/translating-collective-memory-of-beslan-russian-statetelevision- (Accessed on January 27, 2020).

Harshini, P., Jayaneela Sneha, T.C. (2019). Influence of Narrative Journalism through Storytelling. International Journal of Linguistics, Literature and Translation. 2(2), 68-89.

Herman, D. (2009). Basic Elements of Narrative. Wiley-Blackwell: Chichester (UK); Malsen (USA), xvi.

Kim, K., Harding, S.-A. (2015). Narrative Theory in Translation Studies: a research symposium. Advancing Research in Translation and Interpreting Studies (ARTIS). Shanghai Jiao Tong University, from 25 to 27 March 2016.

Kornaukhova, N.G. (2011). Translation Strategies in the Aspect of Manipulations with the Mind. Bulletin of Irkutsk State Linguistic University, 15, 90-96. (in Russian)

Moloney, K. (2012). Transmedia Journalism as a Post-Digital Narrative. ATLAS. University of Colorado. Retrieved from: https://www.academia.edu/2210089/Transmedia_Journalism_as_a_Post-Digital_Narrative (Accessed on January 27, 2020).

Moshonkina, Y.N. (2016). Lawrence Venuti and "The French Theory”: on Post-Structuralist Roots of the New Theory of Translation. Philosophic Matters, 3, 61-71. (in Russian)

Pronin, A.A. (2016). Television as a Narrator: Biographic Narrative in Modern Documentary Filmmaking. St.-Petersburg: "Petropolis" Publishing House. (in Russian)

Shelestyuk, Y.V., Gritsenko, E.D. (2016). On Foreignisation and Domestication in Translation and Possibilities of Their Linguistic Evaluation. Bulletin of Chelyabinsk State University. Philological Sciences, 4(386), 202-207. (in Russian) 
Snell-Hornby, M. (2006). The Turns of Translation Studies: New paradigms or shifting viewpoints? Amsterdam/Philadelphia: John Benjamins Publishing Company.

Somers, M.R., Gibson, G.D. (1994). Reclaiming the Epistemological 'Other': Narrative and the Social Constitution of Identity. Social Theory and the Politics of Identity. Oxford UK \&Cambridge USA: Blackwell, 37-99.

Winner: Citizenfour. The Doc Impact Award 2016. Retrieved from: https://impactguide.org/static/library/citizenfour.pdf (Accessed on September 13, 2020). 